\title{
ALMANDITIC GARNET-RICH METAMORPHIC ROCKS AS AN ORIGINAL SOIL DEVELOPED DURING PRECAMBRIAN
}

\author{
SHIGUEMI FUJIMORI* \& WILLIAM S. FYFE**
}

\begin{abstract}
The precambrian terrains of Salvador, Bahia, are made mainly of metamorphic rocks of very high grade (granulite facies) with more than $2.2 \mathrm{Ga}$ in age. The main rock types are basic granulites and acid granulites, cut by small pegmatites, aplites and diabase dykes. Some of the acid granulites of Farol da Barra, Salvador, contain almanditic garnet, sillimanite and cordierite. These mineral assemblages are considered originally as residual soil developed on basic granulites and this residual soil was metamorphosed up to gtanulite facies.
\end{abstract}

\begin{abstract}
RESUMo Os terrenos pré-cambrianos sobre os quais repousa a Cidade Alta do Salvador são constituídos predominantemente de rochas metamórficas de intensidade muito elevada (fácies granulito) e de idades superiores a 2,2 bilhð̃es de anos. São granulitos ácidos e básicos cortados por pegmatitos, aplítos e diques de diabásio. Entre os granulitos ácidos sobressaem algumas variedades ricas em granada, cordierita e sillimanita, como no Farol da Barra, em Salvador. As associaçб̃es ricas em granada, e com sillimanita e cordierita são consideradas originalmente como um solo residual que se formou sobre os granulitos básicos e que posteriormente foi metamorfizado intensamente até a fácies granulito. Para rochas tão antigas como essas e que são comuns em muitas outras partes do mundo, a possibilidade de identificar um nível original de solos residuais é muito importante, não só para a interpretação : de certas condições ambientais predominantes naquele períođo, mas também para fins de prospeç̧̃̃o mineral em terrenos metamorfizados intensamente.
\end{abstract}

INTRODUCTION Garnet-bearing rocks are very common in metamorphic terrains. There are many of garnets, but the almandine-rich one occurs very often in intermediate to high-grade metamorphic rocks. Since Barrow's work on Scottish Highlands (1893), the garnets are considered as one of the progressive regional metamorphic zone indicators.

Very often garnet-containing rocks form conspicuous bands with variable thickness and size. In the granulitic terrains of Salvador, Bahia, there are many bands with almandine-rich garnets. Some of these bands are short thin layers and also they occur in the outer border of some spherical metaultramafic rocks.

Many types of high-grade metamorphic rocks with 2.2 Ga (Cordani et al 1979) were mapped in Farol da Barra, Salvador, Bahia (Fig. 1). From petrographic and chemical studies of those rocks and field relations, a possible former precambrian paleosoil metamorphosed to granulitic facies was concluded for the origin of the rocks with almandinerich garnets.

PETROGRAPHIC TYPES In the small portion of Farol da Barra, Salvador, the following mineral assemblages were studied:

a) clinopyroxene ( \pm plagioclase) (diopsidites)

b) quartz + orthopyroxene ( \pm plagioclase)

c) orthopyroxene + plagioclase

e) garnet + quartz \pm plagioclase (kinzigite) $\quad$ acid

g) garnet + sillimanite + cordierite + quartz \pm plagiociase granulites
The proportion of minerals in each assemblage is highly variable as shown in Table 1 . Dykes of aplite cut some of the previous rocks (Fig. 1). The garnet-bearing rocks contact diopsidites and basic granulites.

Clinopyroxene (tplagioclase) (diopsidites) The diopsidites are greenish-coloured massive rocks with fine to coarsegrained texture. They occur as small lenticular bodies of 5 $\mathrm{cm}$ up to $50 \mathrm{~m}$ in length. The lenses of diopsidites are aligned due possibly to the boudinage. These lenses in Farol da Barra are surrounded concentrically by or associated with light-bluish gray rock composed mainly by quartz and orthopyroxene ( \pm plagioclase \pm biotite).

The essential minerals of diopsidites are diopside with variable but generally small amount of plagioclase, quartz, biotite, sphene and sometimes scapolite.

The diopside is light-greenish colour in hand specimen, granoblastic texture with boundaries of grains presenting triple points. Small plagioclase and biotite inclusions are common. The structural composition of diopside derived from electron microprohe analyses is $\left(\mathrm{Ti}_{0.00} \mathrm{Mn}_{0.01}\right.$

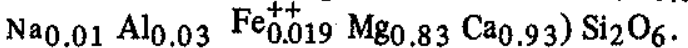

The plagioclase are small irregular grains, $0.1-0.2 \mathrm{~mm}$ in size, and they are intersticial to diopside grains. The plagioclases as inclusions in diopside are also very irregular and very often they show "shard" - like shape. Small replacem" ent by carbonates is observed and the composition is around Ang0.

The biotite is strongly pleochroic from pale yellow to reddish brown and it is derived from diopside.

\footnotetext{
* Instituto de Geociências da Universidade Federal da Bahia. Rua Caetano Moura, 123, CEP 40000, Federação, Salvador, Bahia, Brazil.

** Dept. of Geology - University of Western Ontario, London, Ontario, Canadá.
} 


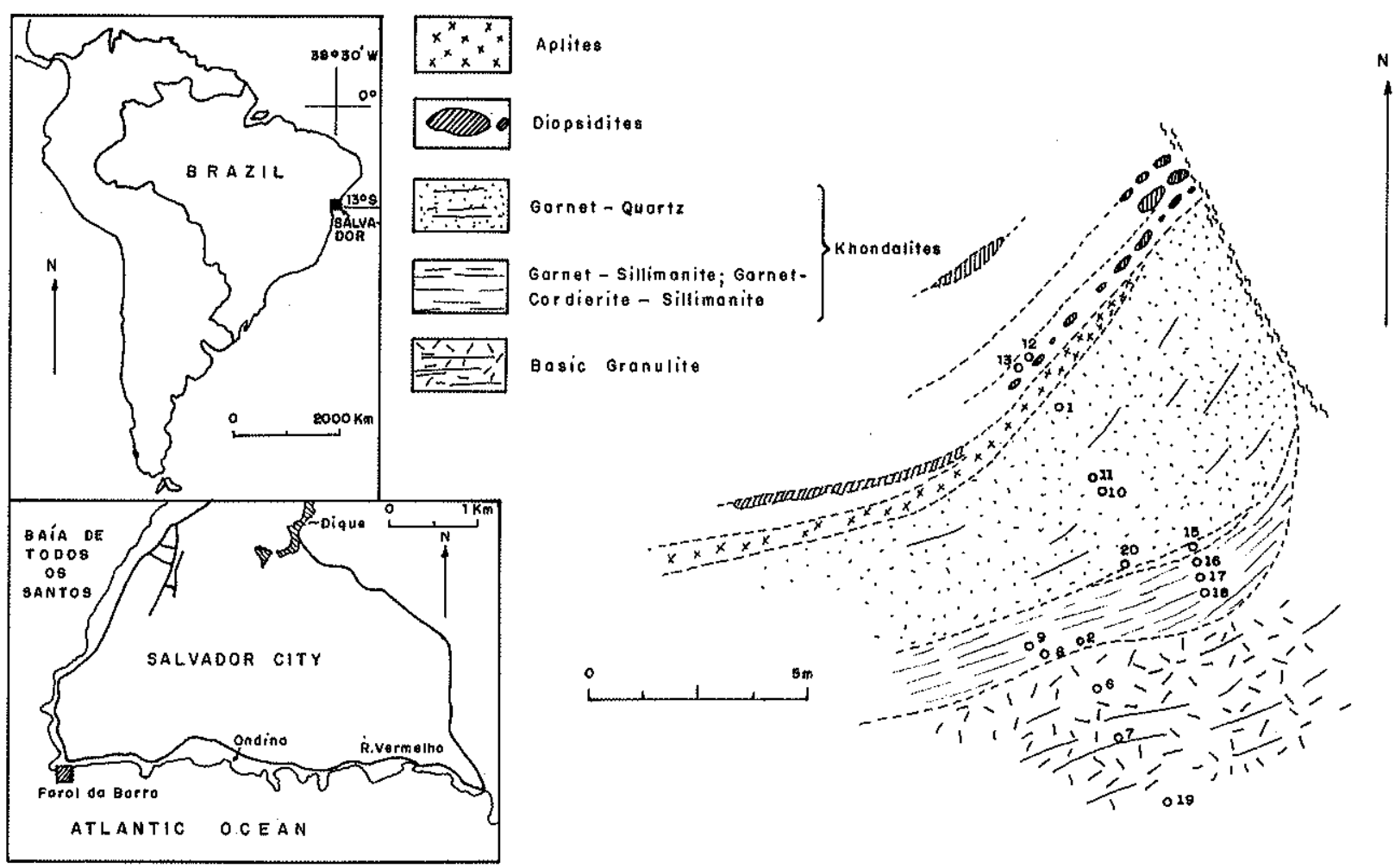

Figure 1 - Garnetiferous granulites of Farol da Barra, Salvador, Bahia, Brazil

Table 1 - Average modal compositions of the Farol da Barra rocks

\begin{tabular}{lccccccc}
\hline & $\mathrm{a}$ & $\mathrm{b}$ & $\mathrm{c}$ & $\mathrm{d}$ & $\mathrm{e}$ & $\mathrm{f}$ & $\mathrm{g}$ \\
\hline Quartz & - & 65 & $1-10$ & $0-5$ & $35-60$ & $30-50$ & $25-50$ \\
K feldspar & $0-5$ & - & tr & - & - & tr & tr \\
Plagioclase & $0-5$ & $10-15$ & $50-60$ & 45 & $10-50$ & $0-5$ & $10-25$ \\
Orthopyroxene & - & $10-15$ & $15-30$ & 20 & - & - & - \\
Clinopyroxene & 95 & - & - & 30 & - & - & - \\
Garnet & - & $0-5$ & - & - & $5-30$ & $15-20$ & $5-25$ \\
Sillimanite & - & - & - & - & - & $15-30$ & $5-25$ \\
Cordierite & - & - & - & - & - & - & $5-15$ \\
Biotite & tr & tr & tr-15 & tr & tr-10 & $0-3$ & $5-15$ \\
Spinel & - & - & - & - & tr & tr & $1-15$ \\
Ilmenite & - & - & tr-4 & 5 & -1 & tr & tr \\
Rutile & - & tr & - & - & tr & tr-1 & tr \\
Corundum & - & - & - & - & - & - & tr \\
Sphene & tr & tr & - & - & - & - & - \\
Zitcon & - & - & - & - & - & - & tr \\
Apatite & - & tr & tr-3 & tr & tr & - & - \\
Hornblende & - & - & - & tr & - & - & - \\
\hline
\end{tabular}

$a, b, c, d, e, f, g-$ mineral assemblages in the text:

a) clinopyroxene ( \pm plagioclase) (diopsidites);

b) quartz + orthopyroxene ( \pm plagioclase);

c) orthopyroxene + plagioclase;

d) orthopyroxene + clinopyroxene + plagioclase;

e) garnet + quartz \pm plagioclase (kinzigite);

f) garnet + sillimanite + quartz (khondalite);

g) garnet + sillimanite + cordierite + quartz \pm plagioclase. 
These diopsidites are derived from original impure carbonate sediments (Sighinolfi et al. 1974).

Quartz-orthopyroxene ( \pm plagioclase \pm biotite) It is light-bluish gray rock, fine grained, with some millimetric greenish spots of diopsidite fragments. This kind of rock is around or associated with diopsidite lenses. Foliation is present due to the elongated bluish-white quartz grains. The foliation is not parallel to the elongation of those small diopside fragments. The essential minerals are quartz and hypersthene with variable amount of plagioclase, biotite, ilmenite, garnet. The quartz grains are elongated with irregular and sutured contacts. The grain size is around 1 to 3 $\mathrm{mm}$ and strong wavy extinction and aligned small fluid inclusions are common. The plagioclases are granular, $0.5 \mathrm{~mm}$ in average size, and the polysinthetic twinning lamelae are often bent. The composition is around $\mathrm{An}_{55}$. The orthopyroxenes are granular, $0.5 \mathrm{~mm}$ in size and they are distributed randomly in quartz-rich portions of the rock. The structural composition is $\left(\mathrm{Ca}_{0.01} \mathrm{Ti}_{0.01} \mathrm{Mn}_{0.01} \mathrm{Al}_{0.03} \mathrm{Fe}_{0.73}^{++}\right.$ $\left.\mathrm{Mg}_{1.24}\right)\left(\mathrm{Al}_{0.08} \mathrm{Si}_{1.92}\right) \mathrm{O}_{6}$. This orthopyroxene is a hypersthene $\mathrm{E}_{\mathrm{n}} 63$.

Basic granulites There are two mineralogical varieties of basic granulites in this portion of metamorphic terrain:

- orthopyroxene + plagioclase

- orthopyroxene + clinopyroxene + plagioclase

These two mineralogical assemblages are interlayered and each layer may have a thickness of fraction of millimeter; so, even in a thin section, both associations may be observed. They are greenish-gray to bluish-gray colour, finegrained and saccharoidal textured rock. The foliation is observed in weathered surface and is due to mineral banding and some elongated quartz grains. Besides clinopyroxene, orthopyroxene and plagioclase, small amounts of quartz, hornblende, biotite, opaque mineral and apatite are generaily present.

The plagioclase are granoblastic, $0.5-0.8 \mathrm{~mm}$ in average size. The contacts beteween plagioclase grains are smooth and straight with triple points, but they are more concave than pyroxene contours. The composition is around $\mathrm{An}_{55-60 .}$

The orthopyroxenes are also granular, $0.5 \mathrm{~mm}$ as average grain size and convex contours. They are light green to light rose in colour and they apper in bands or layers with abundant opaque minerals. In these layers clinopyroxene is absent or very scarce. The orthopyroxene presents $2 \mathrm{~V}(\sim) \cong$ $60^{\circ}$ and distinct disperson $r>v$ and schiller texture. Opaque minerals are around pyroxene grains. The structural composition of orthopyroxenes is $\left(\mathrm{Ti}_{0.01} \mathrm{Na}_{0.01} \mathrm{Mn}_{0.02}\right.$ $\left.\begin{array}{lllll}\mathrm{Ca}_{0.03} & \mathrm{Fe}_{0.86} & \mathrm{Mg}_{1.11}\end{array}\right)\left(\begin{array}{llll}\mathrm{Al}_{0.03} & \mathrm{Si}_{1.97}\end{array} \mathrm{O}_{6}\right.$ or $\mathrm{E}_{\mathrm{n} 56} \quad$ ap* proximately.

The clinopyroxene is light green and granular, with 0.5 $\mathrm{mm}$ in average grain size. The clinopyroxene grains concentrate in some layers parallel to orthopyroxene-rich bands. There are inclusions of hornblende which is an alteration of pyroxene. The clinopyroxene is diopside $\left(\mathrm{Ti}_{0} .01 \mathrm{Mn}_{0.02}\right.$ $\left.\mathrm{Al}_{0.02} \mathrm{Na}_{0.02} \mathrm{Fe}_{0.25} \mathrm{Mg}_{0.77} \mathrm{Ca}_{0.94}\right)\left(\mathrm{Al}_{0.05} \mathrm{Si}_{1.96}\right) \mathrm{O}_{6}$.

The biotite is strongly pleochroic from dark reddish brown to light yellow and it is associated with pyroxenes and opaque minerals. These opaque minerals are mostly ilmenite and they are interstitial to orthopyroxene grains. Some pyrite is also present. Apatite is subhedral to anhedral and it is more abundant in orthopyroxene layers. The apati- te grain size is in the range $0.1-0.2 \mathrm{~mm}$. The hornblende is olive green and it is an alteration of pyroxenes. The quartz is granular to slightly elongated, ranging in grain size from $0.1 \mathrm{~mm}$ to $0.5 \mathrm{~mm}$. Lenses of quartz grain agglomerate and elongated isolated grains are oriented parallel to the foliation of the rock. The quartz shows wavy extinction and aligned small fluid inclusions.

Garnet - quartz - plagioclase (t biotite) assemblage This kind of assemblage is bluish gray, fine-grained and saccharoidal rock. The foliation is due to elongated quartz grains. The essential minerals are quartz, garnet and plagioclase with variable amounts of biotite, $K$ feldspar and traces of apatite, ilmenite, zircon and spinel.

The quartz grains are bluish milky colour in hand specimen and they are xenoblastic and elongated parallel to the foliation of the rock. The individual quartz grains are around $0.5-2.0 \mathrm{~mm}$ and they form assemblage within which the sutured contact is common. Wavy extinction is normal but the quartz grains as inclusions in garnets show normal extinction.

The plagioclases are granular, $0.5 \mathrm{~mm}$ in average grain size, and they form agglomerates with potassium feldspars of similar grain size. The contacts between their grains are straight. The composition of plagioclases is around $\mathrm{An}_{35}$. The potassium felspars are very often perthitic and show wavy extinction. Myrmekitic texture is common.

The biotite is also strongly pleochroic from pale yellow to deep reddish brown and with $2 \mathrm{~V} \cong 0^{\circ}$. It is associated with garnets, through the grain fractures and as "pressure shadow" around them.

The garnet is granoblastic to subhedral and $0.5-2,0 \mathrm{~mm}$ in size. It is poikiloblastic with rounded quartz inclusions and also spinel and rutile needles. These rutile needles and elongated rounded quartz grains in garnets are arranged very often in helicitic texture. The chemical composition of garnet is given in Table 2 and its structural composition is $\left(\mathrm{Mn}_{0.04} \mathrm{Ca}_{0.21} \mathrm{Mg}_{2.05} \mathrm{Fe}_{3.73}\right)\left(\mathrm{Ti}_{0.01} \mathrm{Al}_{3.98}\right) \mathrm{Si}_{6} \mathrm{O}_{24}$ or approximately alm 62 py34 gros $5 \mathrm{sp}_{1}$. Zircon and apatite are small subhedral prismatic to eggshaped grains.

Table 2 - Chemical composition of garnets from Farol da Barra, Salvador

\begin{tabular}{lrrr}
\hline & 1 & 2 & \multicolumn{1}{c}{3} \\
\hline $\mathrm{SiO}_{2}$ & 38.82 & 38.52 & 38.84 \\
$\mathrm{TiO}_{2}$ & 0.04 & 0.08 & 0.05 \\
$\mathrm{Al}_{2} \mathrm{O}_{3}$ & 21.93 & 20.61 & 22.00 \\
$\mathrm{FeO}^{*}$ & 29.04 & 28.54 & 29.42 \\
$\mathrm{MnO}$ & 0.27 & 0.58 & 0.41 \\
$\mathrm{MgO}$ & 8.84 & 8.34 & 8.28 \\
$\mathrm{CaO}$ & 1.26 & 3.71 & 1.04 \\
$\mathrm{Na}_{2} \mathrm{O}$ & - & - & - \\
$\mathrm{K}_{2} \mathrm{O}$ & - & - & - \\
$\mathrm{Cr}_{2} \mathrm{O}_{3}$ & - & - & - \\
\hline & 100.20 & 100.38 & 100.04 \\
\hline
\end{tabular}

1 - Garnet from gamet-quartz ( \pm plagioclase) assemblage :

2 - Garnet from garnet-sillimanite-quartz assemblage

3 - Garnet from garnet-sillimanite-cordierite assemblage

(Electron microprobe analyses at University of Western Ontario, Dep. of Geology) 
Garnet-sillimanite-quartz ( \pm plagioclase \pm biotite) and garnet-sillimanite-cordierite-quartz-plagioclase ( \pm spinel \pm corindum \pm biotite) assemblages These two assemblages are generally not distinguishable in hand specimen or in the field. They are grayish-white coloured, fine, saccharoidal and porphyroblastic rock. Slight foliation and milonitization are observed. Garnets are the porphyroblasts floating in a matrix of quartz, sillimanite, and cordierite. The essential minerals of the first assemblage (khondalite) are quartz, garnet, sillimanite and small amounts of spinel, rutile, biotite and plagioclase. The amount of biotite increases in some parts of the rock. The second assemblage is made by quartz, garnet, sillimanite, cordierite and plagioclase with variable amounts of biotite and traces of spinel, corundum, rutile, ilmenite. These minerals are irregularly distributed and the plagioclases are seggregated in some parts of the rock.

Quartz is xenoblastic elongated grains with sutured contacts, wavy extinction and with small needle-like mineral and fluid inclusions. In biotite-rich portion of the rock the quartz grains show normal extinction. The average grain size is in the range $0.5-1.0 \mathrm{~mm}$, but in milonitized zone is smaller and the mortar texture is observed. Generally the quartz grains form elongated agglomerates oriented parallel to the rock foliation. It occurs also as rounded inclusions in garnet, with normal extinction.

The sillimanite is euhedral to subhedral prismatic grains, $0.2-1.0 \mathrm{~mm}$ in average length. They form very often lenticular agglomerates oriented parallel to the general foliation of the rock (Fig. 2). They form also agglomerates with garnet, cordierite, spinel, corundum and biotite. Square or rectangular cross sections of sillimanite are common.

Garnets are generally granular to slightly elongated grains and rose coloured in hand specimen. The grain size varies in the range $(0.5 .3 .0 \mathrm{~mm}$ and they are poikiloblastic with rounded and some elongated inclusions of quartz, feldspar, spinel. The spinel as inclusion is very irregular shaped.

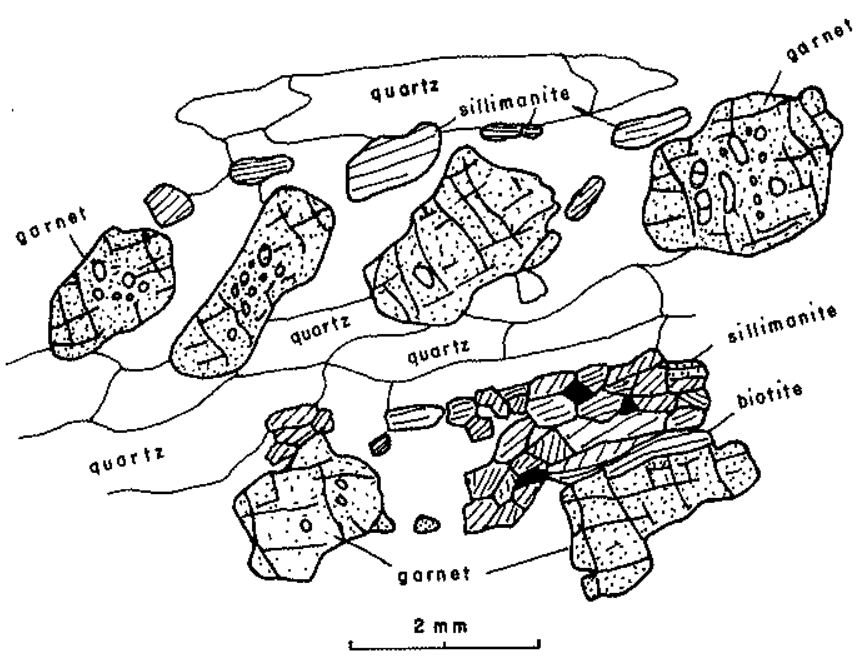

Figure 2 - Garnet-sillimanite-quartz assemblage

The elongated quartz inclusions are oriented but their orientation is not parallel to the general orientation of the rock (Fig. 2) and different grains of garnet show different orientation of those inclusions. Also the quartz and feldspar inclusions concentrate generally in central portion of the garnet grain and frequently helicitic texture is observed. "Atoll"-shaped garnet grains are also observed. The electron microprobe analyses did not show composition zoning in garnets and their structural composition is $\left(\mathrm{Mn}_{0.09} \mathrm{Ca}_{0.20}\right.$ $\begin{array}{llllll}\mathrm{Mg}_{2.23} & \mathrm{Fe}_{3.49} & \left(\mathrm{Ti}_{0.01}\right. & \mathrm{Al}_{3.96}\end{array}\left(^{\mathrm{Si}_{6.01}} \mathrm{O}_{24}\right)$ or $\mathrm{alm}_{58}$ py $_{37} \mathrm{gr}_{3} \mathrm{Sp}_{2}$ for garnet-sillimanite-quartz assemblage (khondalite) and $\left(\mathrm{Mn}_{0.06} \mathrm{Ca}_{0.18} \mathrm{Mg}_{1.92} \mathrm{Fe}_{3.80}\right)\left(\mathrm{Ti}_{0.01}\right.$ $\left.\mathrm{Al}_{4.01}\right)\left(\mathrm{Si}_{6,01} \mathrm{O}_{24}\right)$ or alm $64 \mathrm{py}_{32} \mathrm{gr}_{3} \mathrm{Sp}_{1}$ for garnet-sillimanite-cordierite-quartz assemblage.

Table 3 - Chemical composition of granulites and garnet-containing rocks, Salvador, Bahia, Brazil

\begin{tabular}{|c|c|c|c|c|c|c|c|c|c|c|c|c|}
\hline & \multirow{2}{*}{$\frac{\text { DIOPSIDITE }}{\text { FBG-14* }}$} & \multicolumn{6}{|c|}{ BASIC GRANULITES } & \multicolumn{5}{|c|}{ GARNET-QUARTZ ASSEMBLAGE } \\
\hline & & FBG-6* & FBG-7* & FBG-15* & FBG-19* & FBG-24** & FBG-25** & FGB-10* & FBG-11* & FBG-13* & FBG-20* & FB-26** \\
\hline $\mathrm{SiO}_{2}$ & 52.32 & 56.15 & 57.62 & 52.64 & 56.30 & 60.39 & 59.53 & 77.28 & 57.23 & 82.18 & 70.95 & 74.53 \\
\hline $\mathrm{TiO}_{2}$ & 0.30 & 1.50 & 0.87 & 1.48 & 0.90 & 0.89 & 1.08 & 0.52 & 0.96 & 0.48 & 0.42 & 0.33 \\
\hline $\mathrm{Al}_{2} \mathrm{O}_{3}$ & 4.90 & 15.20 & 18.09 & 17.60 & 16.30 & 17.16 & 15.91 & 9.33 & 17.60 & 6.82 & 14.36 & 9.45 \\
\hline $\mathrm{Fe}_{2} \mathrm{O}_{3}$ & 3.89 & 6.96 & 4.19 & 4.82 & 4.51 & 2.30 & 2.05 & 3.81 & 7.02 & 2.69 & 2.82 & 2.02 \\
\hline $\mathrm{FeO}$ & 2.44 & 5.02 & 4.48 & 7.19 & 3.37 & 6.36 & 7.30 & 2.98 & 5.05 & 2.60 & 1.51 & 6.10 \\
\hline $\mathrm{MnO}$ & 0.16 & 0.14 & 0.11 & 0.49 & 0.10 & 0.19 & 0.13 & 0.06 & 0.17 & 0.05 & 0.05 & 0.08 \\
\hline $\mathrm{MgO}$ & 11.97 & 3.74 & 2.96 & 6.44 & 4.08 & 4.15 & 5.22 & 1.80 & 4.02 & 1.40 & 1.33 & 3.12 \\
\hline $\mathrm{CaO}$ & 22,54 & 5.72 & 5.32 & 5.43 & 6.76 & 3.62 & 4.69 & 1.17 & 2.51 & 0.49 & 1.62 & 1.13 \\
\hline $\mathrm{K}_{2} \mathrm{O}$ & 0.06 & 1.70 & 1.11 & 1.44 & 1.55 & 1.24 & 1.30 & 2.11 & 2.11 & 2.04 & 4.08 & 0.32 \\
\hline $\mathrm{Na}_{2} \mathrm{O}$ & 0.27 & 2.72 & 3.48 & 1.84 & 3.91 & 2.25 & 0.51 & 0.79 & 2.38 & 0.72 & 1.99 & 2.71 \\
\hline $\mathrm{P}_{2} \mathrm{O}_{5}$ & - & - & - & - & - & - & - & - & - & - & - & - \\
\hline L.I. & 1.36 & - & - & 0.41 & - & - & - & - & - & 0.18 & 0.20 & - \\
\hline
\end{tabular}

* Analyses by Linhares, P. (1983), CEPED-SME, Bahia

** Analyses by Sighinolfi, G. (1972)

Sample Numbers FBG (Fig. 1) 
Table 3(cont.)

\begin{tabular}{|c|c|c|c|c|c|c|c|}
\hline & \multicolumn{3}{|c|}{ GARN. - SILLIM. ASSEMBLAGE } & \multicolumn{4}{|c|}{ GARNET - CORDIER. - SILLIM. ASSEMBLAGE } \\
\hline & FBG $2 *$ & FBG-16* & $\mathrm{FB}-22 * *$ & $\mathrm{FB}-21 * *$ & $\mathrm{FB}-23 * *$ & $\mathrm{FB}-27 * *$ & FBG-8* \\
\hline $\mathrm{SiO}_{2}$ & 65.98 & 62.18 & 63.05 & 54.77 & 56.52 & 50.66 & 51.51 \\
\hline $\mathrm{TiO}_{2}$ & 1.29 & 0.76 & 0.89 & 0.80 & 1.17 & 1.06 & 1.12 \\
\hline $\mathrm{Al}_{2} \mathrm{O}_{3}$ & 17.57 & 22.98 & 19.87 & 23.53 & 22.57 & 23.11 & 24.04 \\
\hline $\mathrm{Fe}_{2} \mathrm{O}_{3}$ & 1.68 & 2.93 & 0.61 & 1.43 & 0.86 & 2.44 & 5.07 \\
\hline $\mathrm{FeO}$ & 3.90 & 3.28 & 5.65 & 6.48 & 4.90 & 8.66 & 4.66 \\
\hline $\mathrm{MnO}$ & 0.08 & 0.10 & 0.12 & 0.16 & 0.17 & 0.26 & 0.13 \\
\hline $\mathrm{MgO}$ & 1.90 & 2.02 & 2.94 & 4.55 & 4.53 & 5.10 & 3.85 \\
\hline $\mathrm{CaO}$ & 2.93 & 0.26 & 1.51 & 2.55 & 2.30 & 2.45 & 3.48 \\
\hline $\mathrm{K}_{2} \mathrm{O}$ & 0.64 & 3.10 & 3.24 & 3.77 & 3.00 & 4.01 & 1.39 \\
\hline $\mathrm{Na}_{2} \mathrm{O}$ & 2.91 & 1.19 & 0.65 & 1.29 & 1.83 & 1.99 & 2.97 \\
\hline $\mathrm{P}_{2} \mathrm{O}_{5}$ & - & - & - & - & - & - & - \\
\hline L.I. & 0.15 & 0.56 & - & - & - & - & - \\
\hline
\end{tabular}

* Analyses by Linhares, P. (1983), CEPED-SME, Bahia

** Analyses by Sighinolfi, G. (1972)

Sample Numbers FBG (Fig. 1)

Spinel is dark green to brownish green and it is associat. ed generally with garnet grain and sillimanite and cordierite agglomerates, but is may appear as isolated grains. In the sillimanite and cordierite agglomerates, the spinel is less abundant in the portion without cordierite. The contours of spinel grains are mainly concave and no reaction. rim is observed between garnet and the inclusions of spinel. Between spinel and feldspars there is a narrow rim of colourless to greenish mineral. The spinel is a hercynite.

The cordierite is present in some layers of the rock associated with garnet, sillimanite and spinel. It is granoblastic and porkiloblastic textured with spinel and small cicular sillimanite inclusions. Complex polysynthetic twinning and simplectitic texture are common. Pleochroic haloes around small zircon crystals are abundant.

The biotite is strongly pleochroic from pale yellow (X) to dark reddish brown ( $Y$ and $Z$ ) and with $2 V \cong 00-30$. It envelops garnet grains and very often it is kinked.

The feldspars are potassic with perthitic texture, wavy extinction and very poor microcline twinning. The rutile crystals are prismatic to needle-like and they are parallel to the general foliation of the rock. They appear also as inclusions in garnet. Few grains of corundum are associated with spinel and opaque, particularly in rocks with cordierite.

ORIGIN OF THE GARNETIFEROUS ROCKS The composition, origin and other characterists of garnets associated with metamorphic rocks were intensely studied by many authors (Griffin et al. 1969, Sighinolfi et al. 1972, Stanton et al. 1978, Stanton 1982, Drugova et al. 1964, Alherton 1966, Harte et al. 1966, Hutton 1962, Muller et al. 1971, Stanton et al. 1977, Sturt 1962, etc.). The origin of garnetiferous rocks of Farol da Barra, Salvador, were studied mainly through the petrography and the bulk chemical composition of the rocks.

The representative rock types were analysed for major oxides in the laboratory of CEPED-BAHIA (Tab. 3).
Analyses made by Sighinolfi (1974) of few other samples of the same area were also added.

The oxide percentages were plotted in the de la Roche diagram of $\mathrm{Al}_{2} \mathrm{O}_{3},\left(\mathrm{Fe}_{2} \mathrm{O}_{3}^{+}+\mathrm{CaO}+\mathrm{TiO}_{2}\right)$ and $\mathrm{SiO}_{2}$.

This diagram in its original form discriminates the fields of igneous trend, calcarenites and arkoses. The plotting, in the same diagram, of some rocks and related residual soils, different types of soils and shales whose chemical analyses were available (Tab. 4) gave other well discriminated field of soils (Fig. 3). The average shales overlap the arkose field of the origin de la Roche diagram, and graywackes are in the lower portion of the shale field.

The residual soil formation processes, from any original rock, indicate a trend in the diagram, from left to right side of the diagram as clearly shown by some rocks and related residual soils: calcareous rock (16) and residual soil (17); basaltic rock (18) and corresponding residual soil (19);

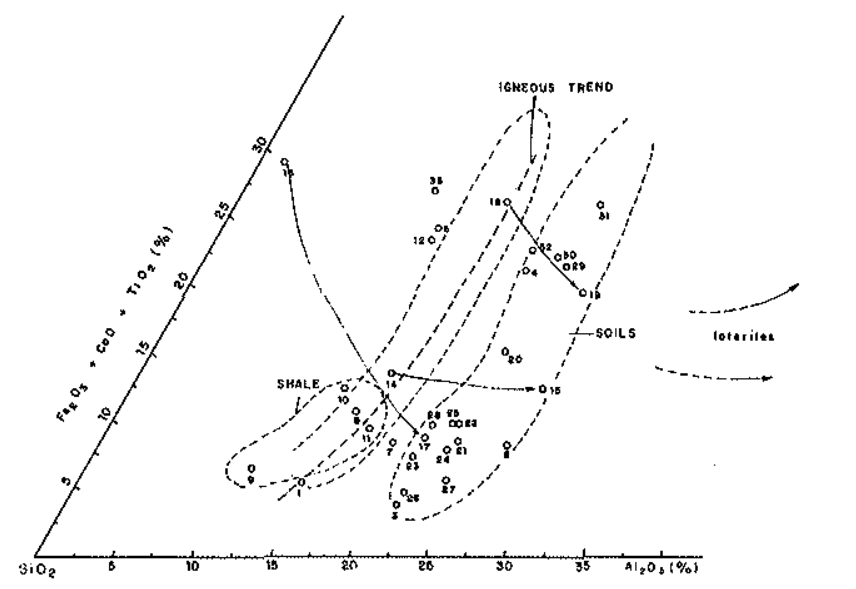

Figure 3 - "Igneous trend" (de la Roche) and fields of shales and several kinds of soils (Tab. 4) 
Table 4 - Chemical composition of some rocks, residual soils, and pelitic materials

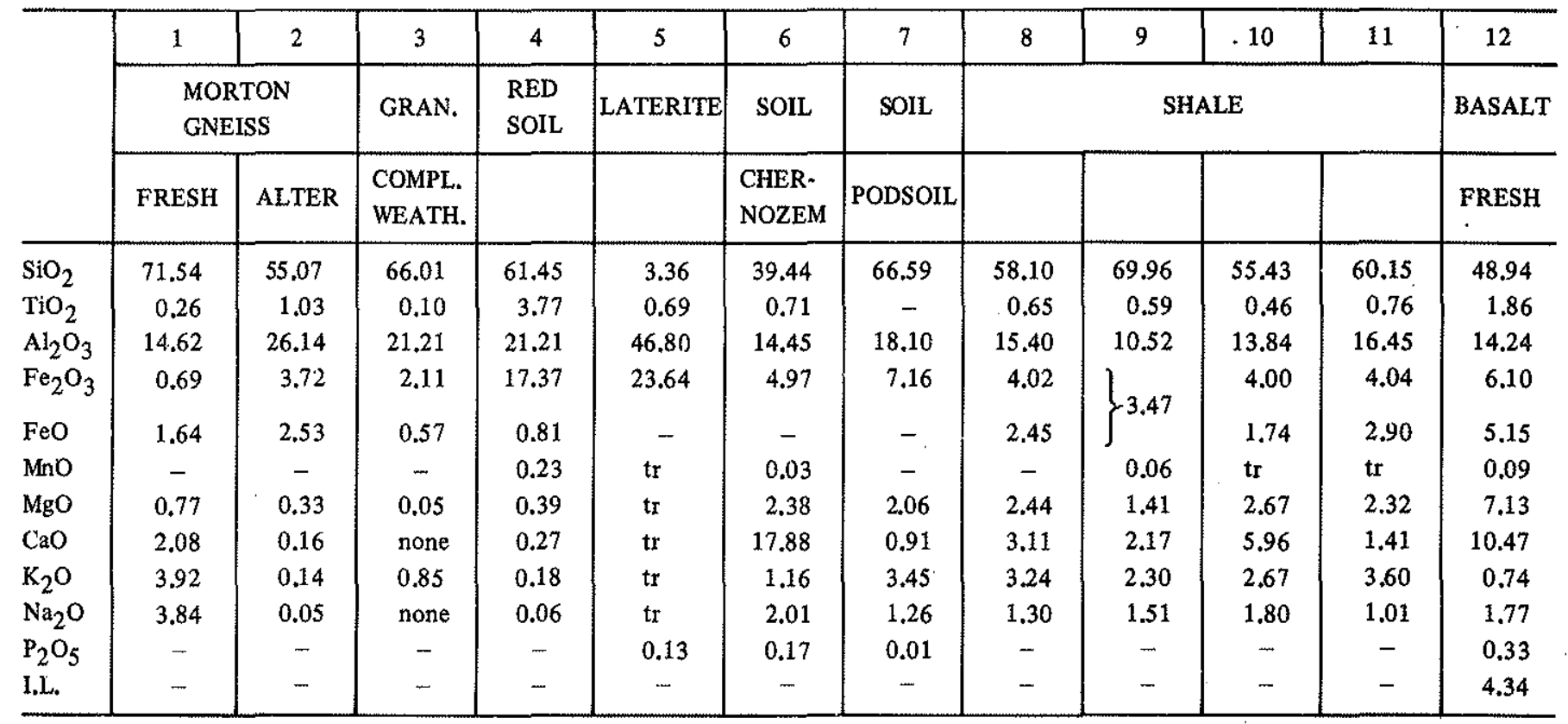

Table 4 - (cont.)

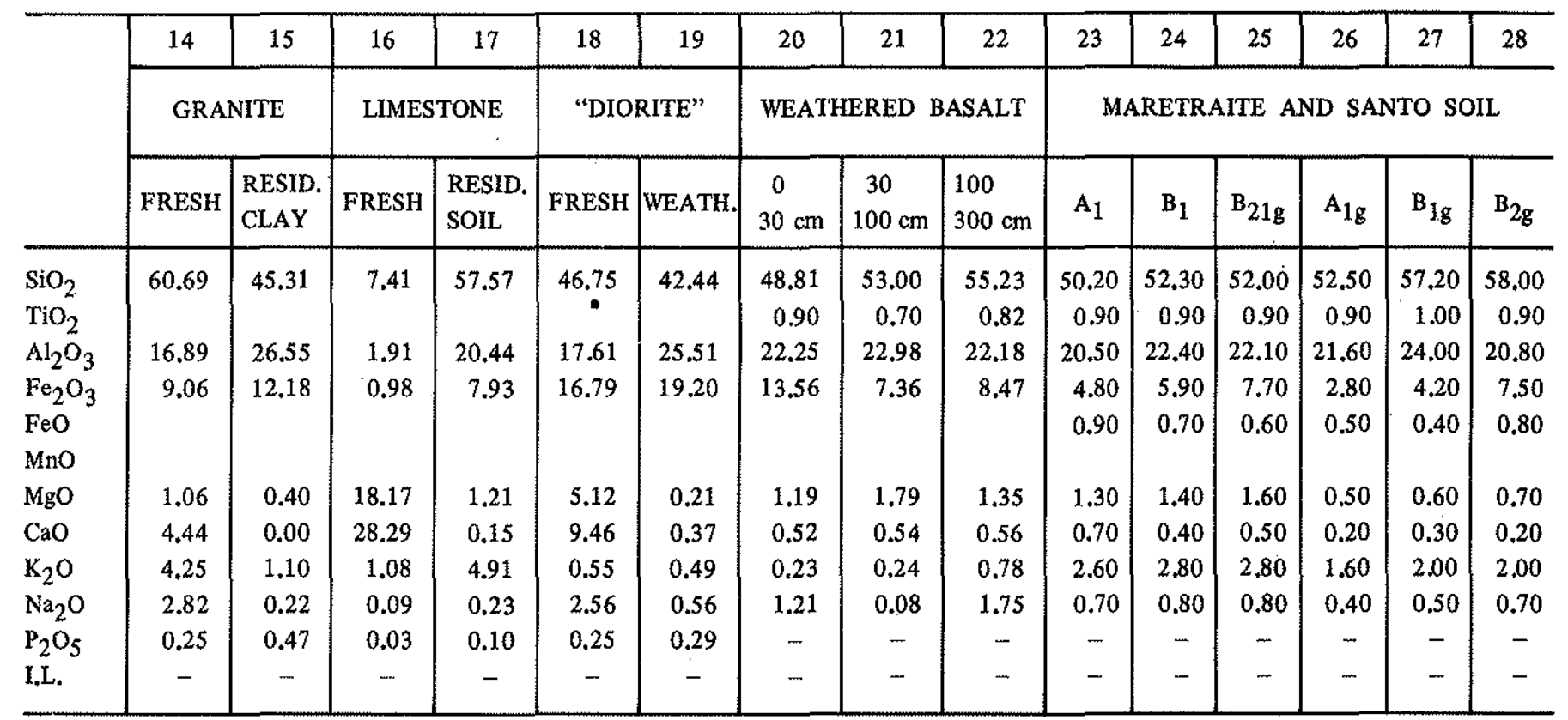

granitoid (14) and residual soil (15). The laterites, lateritic materials and bauxites are far right on the diagram (Fig. 3).

This same trend is also observed by granulites and their residual soils of Salvador, Bahia, when the tropical conditions prevail. The chemical compositions of these granulites and residual soil (Sighinolfi et al. 1973) were plotted in the same diagram (Fig. 4). A possible igneous nature of granulites, a clear discrimination of residual soil and the trend indicated in the first diagram are clearly observed.

The chemical composition through a soil profile should be considered. The soil profile developped on rocks is normally divided in several horizons A, B, C, etc., with other subhorizons. The compositions of these horizons of some profiles plotted on the diagram $\mathrm{Al}_{2} \mathrm{O}_{3} \mathrm{X}\left(\mathrm{Fe}_{2} \mathrm{O}_{3}^{+}+\mathrm{CaO}+\right.$ $\mathrm{TiO}_{2}$ ) $\times \mathrm{SiO}_{2}$ show the general tendency observed in previous diagram, that is, a trend toward the enrichmet of alumina and iron oxides. But a special behaviour of the upper horizons (A and $B$ ) is noticed. From fresh rock to $B$ horizons of the residual soil the trend is toward the enrichment of $\mathrm{Al}_{2} \mathrm{O}_{3}$ and $\mathrm{Fe}_{2} \mathrm{O}_{3}$, but from some subhorizon $\mathrm{B}$ to $\mathrm{A}$ horizon, an inverse trend toward the $\mathrm{SiO}_{2}$ enrichment is clearly observed, as indicated by arrows in the dia. gram. Many A horizons of soils fall in the field overlapping the arkoses and shales (Fig. 5). 
Table 4 -(cont.)

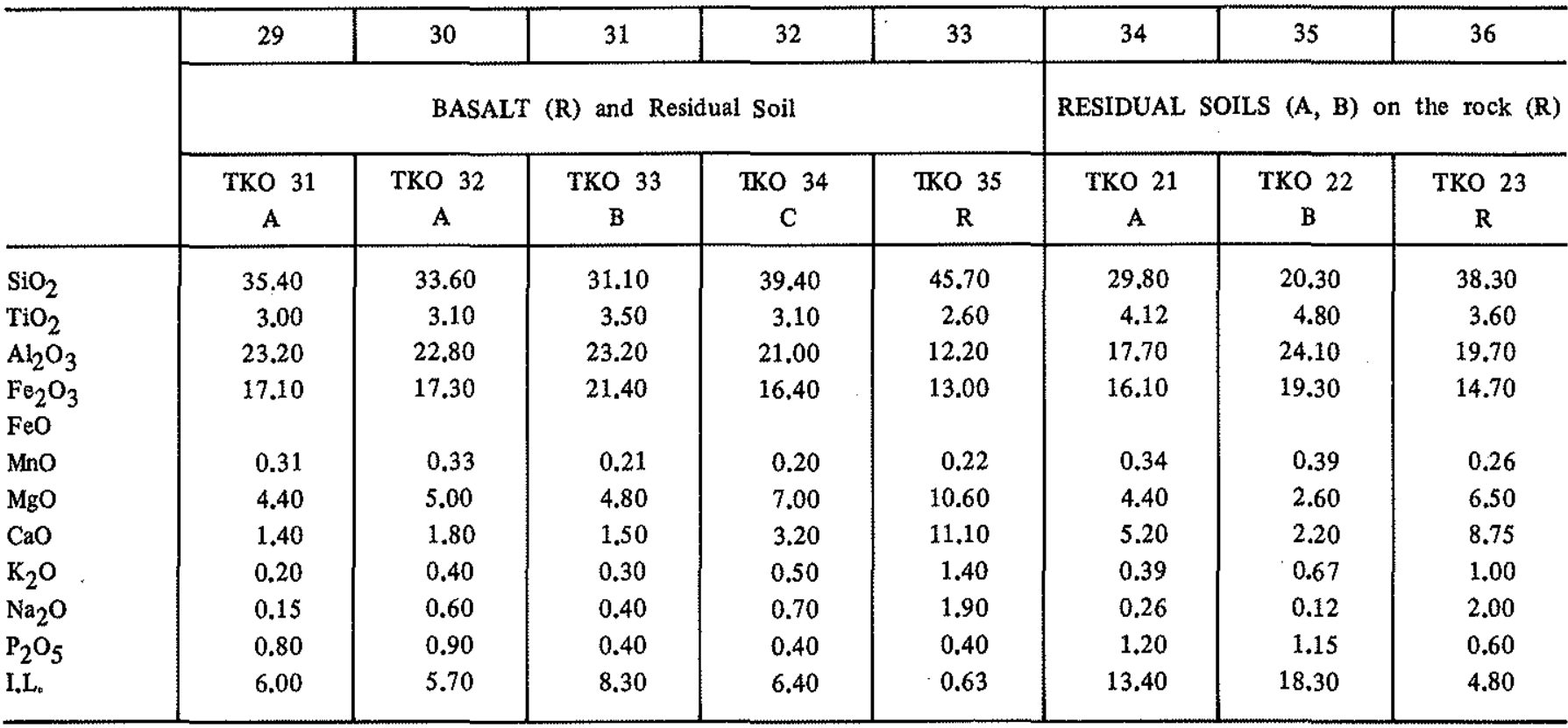

1 and 2 - Morton gneiss fresh and altered, Redwood Falls, Minnesota. Goldich, S.S., analyst. In: Pettijohn, F.J., 1949, Sedimentary Rocks (Goldich 1938). p. 378.

3 - Completely weathered granite, Hong-Kong granite, Gindrinker's Bay, Hong-Kong area. Willman, A., analyst. In: Pettijohn, F.J. 1975, Sedimentary Rocks. p. 280.

4 - Red Soil. In: Suy, J.B. 1971, Genesis and evolution of red and black basaltic soils in Cambodja, Proc. Bandung Symposium on Soils and Tropical Weathering, UNESCO, p. 117.

5 - Laterites. In: Persons, B.S. 1970, Laterite, genesis, location, Use. PLENUM.

6 - Chernozen soil. In: Moniz, A.C. Elementos de Pedologia, 1972, p. 214.

7 - Podsol soil. In: Moniz, A.C. Elementos de Pedologia, 1972, p. 214.

8 - Average shale of Clarke, 1924. In: Pettijohn, F.F. 1949, Sedimentry Rocks. p. 271.

9 - Composite analyses of 235 samples of Mississipi Delta, Stciger, G., analyst. In: Pettijohn, F.J, 1949, Sedimentary Rocks. p. 271.

10 - Composite sample of 27 Mesozoic and Cenozoic Shales, Stokes, H.N. In: Clarke, F.W. 1924, Data of geochemistry. U.S. Geological Surv., Bull. 770 , p. 552 .

11 - Composite Sample of 51 Paleozoic Shales, idem.

12 - Basalt. In: Suy, T.B. 1971, Genesis and evolution of red and black basaltic soils in Cambodja, Proc. Bandung Symposium on Solls and Tropical Weathering, UNESCO.

14 and 15 - Granite, fresh and residual soil. In: Lyon, T.L., Buckman, H.O.; Brady, N.C. 1952, The nature and properties of soils, The MaCmillan Co., p. 302.

16 and 17 - Limestone, fresh and residual soil: idem.

18 and 19 - "Dioite", fresh and weathered. In: Robinson, G.M. 1960, Los Suelos, constitución y clasificación, Omega, Barcelona, p. 61.

20, 21 and 22 - Profile of weathered basalt, Alayao, Camarines Norte, Phillippines. Tamesis, E.V. \& Salita, D.C. 1971, Some aspects of lateritic soil formation in the Dahican-Alayo area, Camarines Norte Province, Phillippines. In: Soils and Tropical Weathering, Proc. Bandung Symposium, UNESCO, p. 127

23, 24, 25, 26, 27 and 28 - Maretraite soil and Santo Soil, Slager, S. \& Van Schuylenborgh, S. 1970, Morphology and Geochemistry of three clay soils of a tropical coastal plain. Centre for Agricultural Publ. and Docum., Wageningen, Dept. of Soil Science, Agric. University, Wageningen, The Netherlands.

$29,30,31,32,33,34,35$ and 36 - Profiles of soils on basaltic rocks (Sieffermann, G. 1973).

The chemical composition of granulites and garnet-bearing rocks of Farol da Barra, Salvador, were plotted in the same diagram (Fig. 6). The granulites fall in the field of igneous trend, very clearly. The diopsidites are close to the calcar nite field and most of the garnet-sillimanite and garnet-sillimanite-cordierite-bearing rocks fall in the field of soils. The quartz-rich varieties of garnet-bearing rocks are in the field of arkoses. This diagram shows the possibility of khondalites and other garnet-rich metamorphic rocks being formed from original soil developped on basic granulites or diopsidites, in the case of Farol da Barra, Salvador. The diopsidites were originally impure sedimentary carbonate rocks. The weathering the metamorphism of this material will produce quartzose rock-like, possibly the quartz-ortho. pyroxene ( \pm plagioclase) assemblage described before.

CONCLUSIONS Almandine-rich garnet-bearing rocks are common in metamorphic terrain of intermediate to high grade. These rocks that received several names as khondalites, kinzigites, etc., occur as bands or layers of variable width associated with other kinds of rocks as basic granulites and diopsidites of Salvador, Bahia. These rocks are also common in many other pre-cambrian terrains distributed all over the world. 


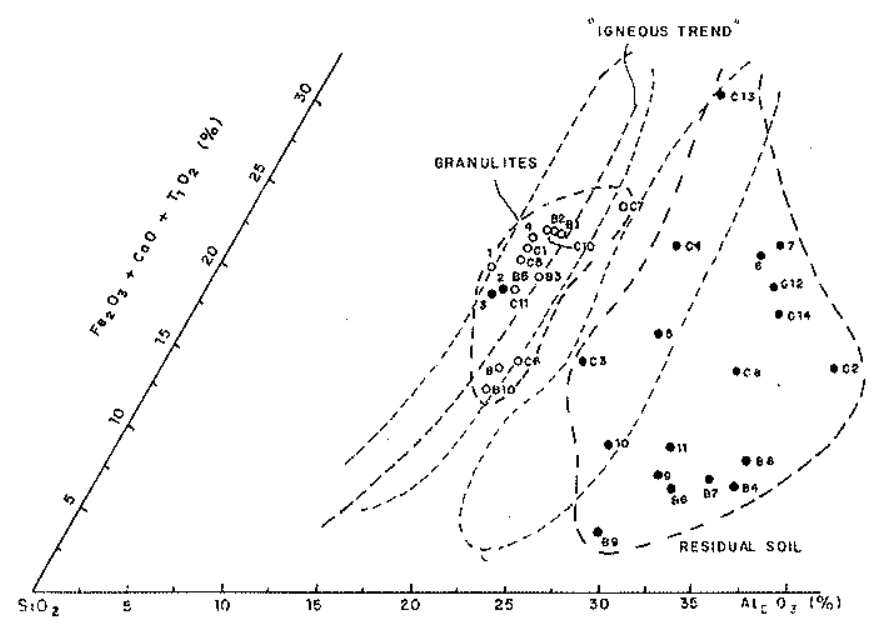

Figure 4 - Granulites (o) and related residual soils (•), Salvador, Bahia, Brazil. (Sighinolfi et al. 1973)

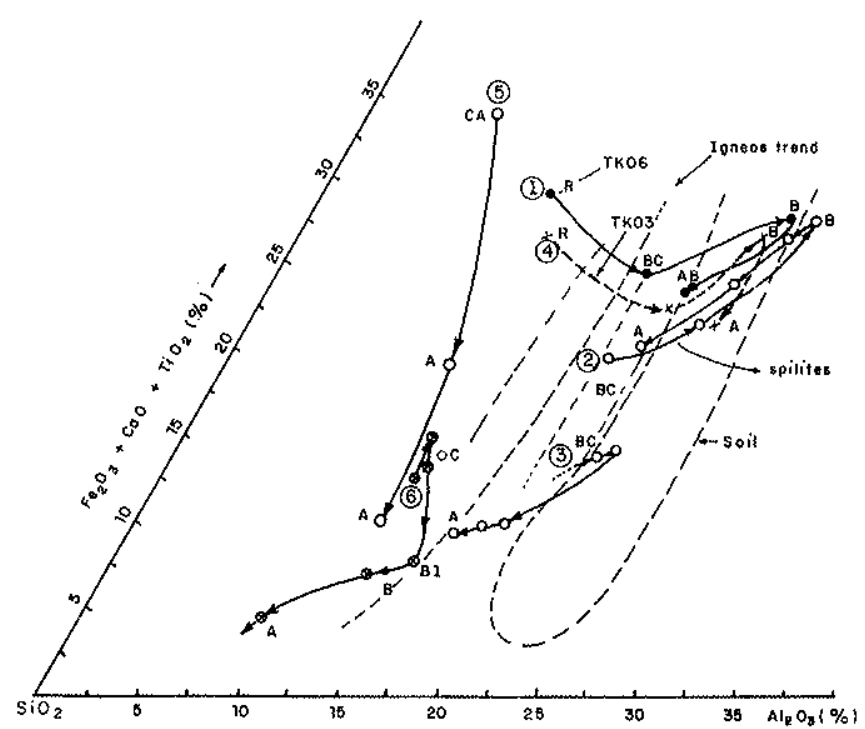

Figure 5 - Soil profiles: 1 - on basaltic lava (Sieffermann 1973); 2 - on spillite (ISM, FAO UNESCO); 3 - on granite (idem); 4 - on pyroclastic basalt (Sieffermann 1973); 5 on calcareous marl (ISM, FAO-UNESCO); 6 - on calcareous loess-like clayey deposits (idem). $(A, B, B C$, etc. $=$ Soil horizons; $C A, R=$ unweathered rocks)

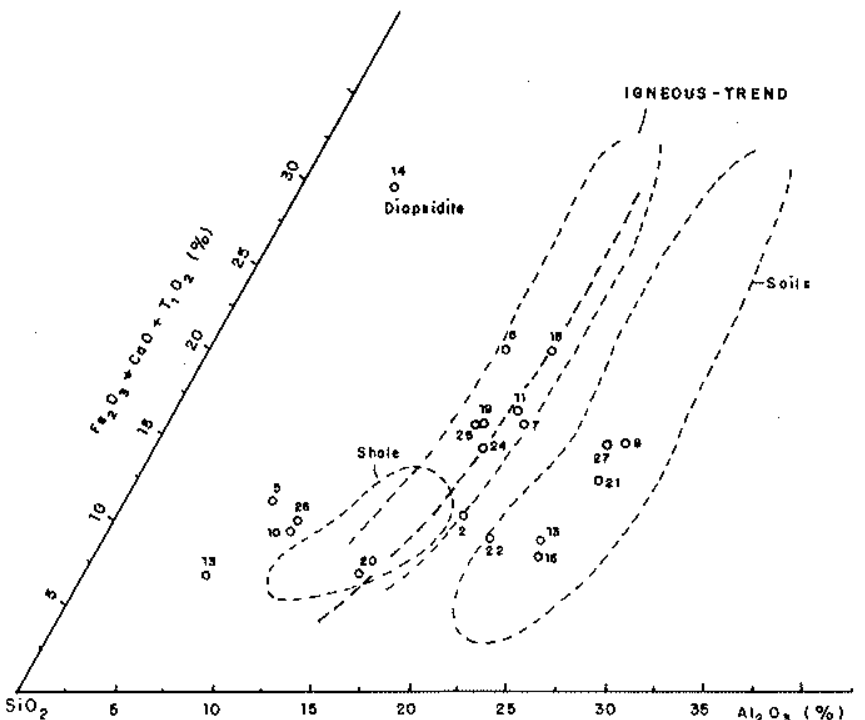

Figure 6 - Farol da Barra (Salvador, Bahia) rocks on the diagram of de la Roche (Tab. 3)

These garnet-bearing rocks and particularly those rich in sillimanite and cordierite were originally a residual soil developped by weathering of basic granulites, in the particular case of Farol da Barra. Around the diopsidites there are quartz-orthopyroxene rocks and this assemblage may be also originally a weathering product of impure sedimentary carbonate rocks.

Acknowledgement The Brazilian CNPq (Conselho Nacional de Pesquisas) is thanked for financial support and also Dr. R. Barnett of the University of Western Ontario. Mr. Warney Bispo de Magalhães and Jaudete Cardoso Rezende are thanked for drawing and typing the manuscript and the Secretary of Mines and Energy of Bahia for doing chemical analyses through the CEPED. We are particularly grateful to CIDA (Canadian International Development Agency) for Canadian support.

\section{REFERENCES}

ATHERTON, M.P. - 1966 - The composition of garnet in regionally metamorphosed rocks. In: PITCHER et al., eds. Controls of Metamorphism. London, John Wiley, p. 281-290.

BARROW, G. - 1983 - On an intrusion of muscovite-biotite gneiss in the Southeastern Highlands of Scotland, and its accompanying metamorphism.J. Geol. Soc. Lond., 49:330-356.

CORDANI, U.G. \& IYER, S.S. - 1979 - Geochronological investigation on the Pre-cambrian granulitic terrain of Bahia, Brazil. Pre-cam. Research, 9 (3/4):255-274.
DRUGOVA, G.M. \& BUGOVA, V.D. - 1964 - Garnets of the granulite facies of the Aldan Shield under conditions of polymetamorphism. Geoch. Internat., 365-371.

GRIFFIN, W.L. \& HEILER, K.S. - 1969 - Parageneses of garnet in granulite facies rocks, Lototen - Vesteraalen, Norway. Contr. Mineral and Petrol., 23: 89-116.

HARTE, B. \& HENLEY, K.I. - 1966 - Zoned almanditic garnets from regionally metamorphosed rocks. Nature, 210:689-692.

HUTTON, C.O. - 1962 - Composition of some garnets in low 
grade schists. Trans. R. Soc. N.Z., 1: 129-133.

MULLER, G. \& SCHNEIDER, A. - 1971 - Chemistry and genesis of garnets in metamorphic rocks. Contr. Mineral. Petrol., 3: $178-200$.

SIEFFERMANN, G. - 1973 - Les sols de quelques régions volcaniques du Cameroun. ORSTOM, Mém. 66, Paris, 183 p.

SIGHINOLFI, G.P.; DE AZEVEDO, L.S.P.; LINHARES, P.S.; MONIZ, A.C. - 1973 - Mineralogical and chemical variations induced by tropical weathering of granulitic rocks from the Brazilian Basement. Rev. Bras. Geoc. 3(2): 71-83.

SIGHINOLFI, G.P. \& FUJIMORI, S. - 1972 - Granadas nos granulitos de Salvador, Bahia: Discussão sobre relações entre sua variação química e reações metamórficas. Rev. Bras. Geoc., 2(3): $141-149$.

SIGHINOLFI, G.P. \& FUJIMORI, S. - 1974 - Petrology and chemistry of diopsidic rocks in granulite terrains from the Brazilian Basement. Atti della Soc. Tosc. di Sci. Natur., Série A, v. LXXXI, p. 103-120.
STANTON, R.L. - 1982 - An alternative to the Barrovian Interpretation? Evidence from stratiform ores. The Austral. Inst: Min. Metall., Proc. no 282, june: 11-32;s. 1.

STANTON, R.L. \& ROBERTS, W.P.H. - 1977 - The composition of garnets at Broken Hill, and their relevance to the origin of the rock. In: BHASKARA RAO ed., Djalma Guimarães Memorial Volume. J. Mineralogia Spec.; s. 1.

STANTON, R.L. \& WILLIAMS, K.L. - 1978 - Garnet compositions at Broken Hill, New South Wales, as indicators of metamorphic processes. Jour. Petrology, 19(3):514-529.

STURT, B.A. - 1982 - The composition of garnets from pelitic schists in relation to the grade of regional metamorphism. Jour. Petrol., 3: 181-191.

MANUSCRITO

Recebido em 27 de julho de 1984 Revisáo aceita em 29 de agosto de 1984

Você não se dedica a nada, a não ser caçar, lidar com cães e pegar ratos. Será uma vergonha para você mesmo e para a família toda. 